\title{
Sosyal Medya Üzerinden Kriz Yönetimi: Krize Yanıt Verme Stratejileri Üzerine Bir Araștırma
}

\author{
Zuhal Gök Demir ${ }^{1}$ \\ Çiğdem Karakaya² \\ Fulya Erendağ Sümer ${ }^{3}$
}

\begin{abstract}
Öz
Örgütlerin içinde bulundukları kriz sürecinde sosyal medya üzerinden paydaşları ile ilişkilerini çok hızı ve aynı zamanda örgütün meşruluğunu destekleyen güvenilir mesajlar ile sürdürmeleri örgütün kurumsal itibarını zedeleyebilecek hasarlardan kaçınmak, paydaşların güvenini korumak ve örgüte ilişkin olumlu davranışsal niyetlerini devam ettirmeleri adına önemlidir. Bu doğrultuda bu mesajların yaratılması için kriz döneminde örgütün söylediği ve yaptığı olarak tanımlanan krize yanıt stratejilerinin içeriği ve etkisinin araştırılması gerekmektedir. Bu nedenle bu çalışma krize yanıt stratejilerinden özür, acıyı paylaşma/anlayış ve bilgilendirici stratejiler arasında algılanan kurumsal itibar, güven ve davranışsal niyet açısından bir farklılık yaratıp yaratmadığını incelemeyi amaçlamaktadır. Alan araştırması ile 2016 yılı Ekim ayında uygunluk örneklemi ile Antalya'daki 1080 Facebook kullanıcısı üniversite öğrencisi araştırmaya dahil edilmiştir. Araştırmanın sonucunda, krize yanıt stratejilerinin kurumsal itibar, güven ve davranışsal niyet üzerindeki etkisi incelendiğinde fark yaratan stratejinin acıyı paylaşma /anlayış stratejisi olduğu tespit edilmiştir.
\end{abstract}

Anahtar kelimeler: Kriz, Kriz Yönetimi, Kriz lletişimi, Krize Yanıt Verme Stratejileri

Atıf: Gök Demir, Z., Karakaya Șatır Ç., \& Erendağ Sümer, F. (2018) Sosyal Medya Üzerinden Kriz Yönetimi: Krize Yanıt Verme Stratejileri Üzerine Bir Araștırma. Akdeniz Üniversitesi Iletișim Fakültesi Dergisi,

(AKIL) Aralık (30), 410-428

1 Dr. Öğr. Üyesi, Alanya Alaaddin Keykubat Üniversitesi İşletme Fakültesi, zuhal.demir@alanya.edu.tr 2 Doç. Dr. Akdeniz Üniversitesi İletişim Fakültesi, csatir@akdeniz.edu.tr

3 Doç. Dr. Akdeniz Üniversitesi Illetişim Fakültesi, fulyaerendag@akdeniz.edu.tr 


\title{
Crisis Management over Social Media: A Research on Crisis Response Strategies
}

\begin{abstract}
It is significant for organisations to maintain their relationships with their stakeholders during crisis over social media rapidly and with reliable messages supporting organisational legitimacy in order to mitigate the potential damages to reputation, maintain trust and behavioural intentions. In this sense, in order to create these messages, the effect and the content of crisis response strategies, which are defined as what an organisation says and does during crisis, needs to be researched. Accordingly, the paper aims to research whether apology, sympathy and informative strategies of crisis response strategies create a difference on the perception of corporate reputation, trust and behavioural intentions. The field study has been carried out in 2016 October with 1080 university students of Facebook users by convenience sampling in Antalya. When the effect of crisis response strategies on corporate reputation, trust and behavioural intentions is investigated, it is found that sympathy is the strategy which creates the difference.
\end{abstract}

Keywords: Crisis, Crisis Management, Crisis Communication, Crisis Response Strategies 


\section{Giriș}

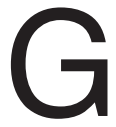
ünümüz örgütlerinin karmaşık, dinamik, belirsiz ve değişken bir ortamda faaliyet göstermeleri ve aynı zamanda sosyal medya aracılığıyla bilginin tüm paydaşlara hızla yayılması örgütlerin geçmiş dönemlerde deneyimlediklerinden daha sık ve yoğun olarak kriz yaşamalarına zemin hazırlamaktadır. Bu nedenle günümüzde kriz iletişimi disiplinine duyulan intiyaç artmaktadır. Çünkü örgütsel krizlerin doğuşu ve gelişimi sosyal ağlarla birlikte dönüşüm göstermiştir. Bu dönüşümde örgütlerin paydaşların talep ve beklentilerine göre kapsayıcı ve bütüncül bir perspektifle kurgulanan kriz iletişim stratejileri ile sosyal medya üzerinden yanıt vermeleri gerekmektedir. Nitekim kriz iletişim stratejilerini sosyal medya üzerinden kurgulayan örgütlerin kriz dönemlerinde tehdit altında kalan en değerli varlıklardan biri olan kurumsal itibarlarının (Fombrun ve van Riel, 2003) da olumlu olarak etkilendiği belirtilmektedir (Ki ve Nekmat, 2014). Paydaşlar örgütleri itibarlı olarak değerlendirdiklerinde örgütten gelen mesajlara olan güven düzeyleri de artmaktadır. Örgütten gelen mesajı güvenilir olarak algılayan paydaşlar bu güveni örgüte yönelik olumlu davranışsal niyet olarak aktarmaktadır ve örgütle olumlu ilişkilerini sürdürmektedirler (Erendağ Sümer vd., 2017). Dolayısıyla; kriz sürecinde örgütlerin itibarlarını korumak, paydaş güveni ve paydaşların olumlu davranışsal niyetlerini sürdürmek amacıyla sosyal medya üzerinden krize yanıt vermeleri örgütler için son derece önemlidir. Çünkü örgütler kriz dönemlerinde sosyal medyayı iyi yönetemediği zaman itibar kaybına uğramaktadır (Duğan, 2018).

Dolayısıyla kriz yönetimi ve kriz iletişimi üzerine yapılan çalışmalar sosyal ağların çeşitlenmesi ile literatürde yeniden ilgi görmeye başlamıştır. (DiStaso vd., 2015). Bu çalışmalar incelendiğinde vaka çalışmaları ve deneysel tasarımlar olmak üzere iki akım dikkati çekmektedir. Ancak çalışmaların daha çok vaka analizleri üzerine odaklandığı görülmektedir. Bu çalışmalar yeni fikirler üretmek amacıyla yararlı olmakla birlikte krize yanıt stratejilerinin diğer kavramlarla olan ilişkisini ve etkisini incelememektedir. Tanımlayıcı nitelikte olan bu çalışmalar paydaşların krize yanıt stratejilerini gerçekte nasıl algıladığı üzerine fazla bir öngörü sunamamaktadır. Dahası vaka çalışmaları kriz iletişimi literatürüne minimal düzeyde kuramsal katkı sağlamaktadır. (Dean, 2004; Dawar ve Pillutla, 2000). Bu nedenle günümüzde kriz iletişim çalışmaları vaka analizlerinin ötesine geçmiş ve sistematik bir şekilde paydaşların algısını ölçmeye yönelik deneysel tasarımlara yönelmiştir. Deneysel tasarımı tercih eden araştırmalar krize yanıt stratejilerinin kriz döneminde paydaşların algısını nasıl etkilediğini incelemektedir (Coombs ve Holladay, 2008). Deneysel tasarımlar bir kavramın başka bir kavram için gerçekten değişime yol açtığını kesin olarak test edebilmenin etkili bir metodudur (Çelebi ve Sezer, 2017a). Ancak krize yanıt stratejilerinin etkilerini inceleyen ampirik çalışmalar hala daha başlangıç seviyesindedir ve geliştirilmeye ihtiyacı vardır (Coombs ve Holladay, 2008). Nitekim dünya literatüründe olduğu gibi Türkiye özelinde de kriz yönetimi ve iletişimi üzerine yapılan çalışmalar vaka analizleri (Duğan, 2018; Canpolat ve Şahiner, 2017; Yıldırım, 2017; Kalaycı, 2017; Çetin ve Toprak, 2016; Aslan, 2015; Çelik ve Çakır, 2015; Çınarlı, 2014; Bat ve Yurtseven, 2014; Şatır ve Gök Demir, 2010; Özdemir ve Yamanoğlu, 2010) temelinde yoğunlaşmaktadır. Ilişkisel analizleri temel alan deneysel tasarımlar (Erendağ Sümer vd., 2017; Çelebi ve Sezer, 2017a; Çelebi 
ve Sezer, 2017b; Akbulut, 2016) son yıllarda tercih edilmeye başlanmasına rağmen literatürde henüz gerekli ilgiyi görmemektedir. Coombs ve Holladay'e (2008) göre aynı kriz için farklı tasarlanmış krize yanıt stratejilerinin etkisini inceleyen çalışmalar en önemli araştırma alanlarından birisidir. Çünkü bu tür karşılaştırmalar kriz iletişim yöneticilerine benzer krizlerle karşılaştıklarında tercih yapma konusunda kolaylık sunmaktadır. Bu nedenle bu çalışma deneysel tasarıma dayanarak aynı kriz için krize yanıt stratejilerinden özür, acıyı paylaşma/anlayış ve bilgilendirici stratejiler arasında algılanan kurumsal itibar, güven ve davranışsal niyet açısından bir farklılık yaratıp yaratmadığını incelemeyi amaçlamaktadır. Çünkü örgütlerin içinde bulundukları kriz sürecinde sosyal medya üzerinden paydaşları ile ilişkilerini çok hızlı ve aynı zamanda örgütün meşruluğunu destekleyen güvenilir mesajlar ile sürdürmeleri örgütün kurumsal itibarını zedeleyebilecek hasarlardan kaçınmak, paydaşların güvenini korumak ve örgüte ilişkin olumlu davranışsal niyetlerini devam ettirmeleri adına önemlidir. $\mathrm{Bu}$ doğrultuda bu mesajların yaratılması için kriz döneminde örgütün söylediği ve yaptığı olarak tanımlanan krize yanıt stratejilerinin içeriği ve etkisinin araştırılması gerekmektedir.

\section{Sosyal Medya Üzerinden Kriz İletișimi}

Kriz iletişim sürecinin en önemli ve en güncel araçlarından biri (Roshan, vd., 2016) olan sosyal medya vazgeçilemez bir iletişim platformu olarak (Scherp vd., 2009), örgütleri güçlü bir online mevcudiyete zorlamaktadır (DiStaso vd., 2015). Coombs'a (2007) göre krizi online olarak yönetememek paydaşlar arasında şüphe uyandırırken, sosyal medya üzerinden kriz durumuna hızlı yanıt veren örgütlerin güvenilir olduğu algısı pekişmektedir (Arpan ve Roskos-Ewoldsen, 2005). Sosyal medya örgütlere paydaşlarıyla kriz süresinde ve sonrasında olan iletişimlerinde sadece en hızlı ve dolaysız bir ortam sağlamamakta aynı zamanda bilgiyi küresel olarak yaymaktadır (González-Herrero ve Smith, 2008; Taylor ve Perry, 2005). Bu nedenle sosyal medya örgütlere kriz dönemlerinde paydaşları ile aktif ve diyaloğa dayalı iletişim fırsatı sunduğu için (Floreddu, vd., 2014) örgütlerin eylemleri sosyal medya sayesinde monologtan diyaloğa doğru bir kayma yaşamaktadır. (Mersham, vd., 2009). Ancak sosyal medya örgütlere paydaşları ile direkt iletişim fırsatı sunarken, mevcut krizin de daha fazla duyulmasına ve krizin yayılmasına da hizmet edebilmektedir. (Roshan, vd., 2016; Ngai, vd., 2015). Ayrıca hassas ve kontrol edilmesi zor bir mecra olan sosyal medyada örgütün yapacağı en küçük bir hata yeni bir kriz doğmasına yol açabilmektedir (Aslan, 2015). Bu nedenle asılsız ve spekülasyona dayalı bilgilerin yayılmasını önlemek amacıyla sosyal medya üzerinden paydaşlara çok hızlı bir şekilde ve aynı zamanda örgütün meşruluğunu destekleyen güvenilir mesajların iletilmesi önem taşımaktadır (Freberg, 2012). Bu mesajların yaratılması için krize yanıt stratejilerin içeriği ve etkisinin kriz yöneticileri tarafından bilinmesi son derece önemlidir. Nitekim Weick (1995) kriz yönetiminde asıl zor olanın krizin büyüklüğünden değil, paydaşları için seçeceği krize yanıt verme stratejisinden kaynaklandığını belirtir. Bu nedenle öncelikle hız, doğruluk ve tutarlılık temelinde paydaşlarla iletişime geçmek önem arz etmektedir. Çünkü belirsizlik paydaşlarda ekstra bir baskı yaratmaktadır ve bu baskı örgütler paydaşlarıyla iletişime geçmek için sosyal medyayı tercih ettikleri zaman daha da artmaktadır (Taylor 
ve Perry, 2005). Literatür hızı bir yanıtı, krizin olumsuzluklarını ortadan kaldırmaya çalışma çabaları açısından avantajlı bulmaktadır (Benoit, 1997). Çoğu kriz durumunun yarattığı olumsuzlukların etkisi, sosyal medyanın hızlı ve gerçek zamanlı bilgi akışı sağlama özelliği sayesinde, krize yanıt verme stratejilerinin etkili ve stratejik bir şekilde kurgulanmasıyla azaltılabilir.

Kriz döneminde örgütün söylemleri konunun paydaşlar tarafından algılanışını belirlediği için krizde uygulanacak yanlış yaklaşım ve kullanılacak yanlış söylemler örgütün imajını olumsuz yönde etkilemektedir. Kriz anında örgütlerin imajları tehdit altında olabileceğinden (Brinson ve Benoit, 1999) örgütler krize yanıt verme stratejilerini, imajlarını bu olası tehditten koruyabilecek şekilde yapılandırmaktadır (Coombs, 1995). Nitekim Benoit (1995) ve Coombs (1995) kriz durumunda örgütlerin imajlarını düzeltmekte kullanabilecekleri stratejiler önermişlerdir. Araştırmalar kriz döneminde örgütün söylediği ve yaptığı olarak tanımlanan krize yanıt stratejilerinin krizden sonra itibarı korumaya hizmet ettiğini göstermektedir (Coombs ve Holladay, 1996). Bu stratejiler özür, acıyı paylaşma/anlayış ve bilgilendirici strateji olarak adlandırılmaktadır (DiStaso vd., 2015).

Özür stratejisinin temel yapısını örgütün krizden kaynaklanan sorumluluğu kabul etmesi ve af dilemesi oluşturur (Patel ve Reinsch, 2003; Fuchs-Burnett, 2002; Benoit ve Drew, 1997). Bu stratejiyi benimseyen örgütler aynı hatayı tekrar yapmaktan kaçınır. (Kellerman, 2006). Pişmanlık ifadesi, vicdan azabı, önleyici tedbirler ve iyileştirme (Patel ve Reinsch, 2003; Fuchs-Burnett, 2002; Cohen, 1999; Benoit ve Drew, 1997) gibi unsurlar da özür stratejisi içerisinde yer almaktadır. Örgüt için finansal olarak en pahalı yanıt olan (Patel ve Reinsch, 2003; Fuchs-Burnett, 2002; Tyler, 1997) özür stratejisi benimsendiğinde, finansal kayıp ve hukuk davaları gündeme gelmektedir. Çünkü özür stratejisi örgüte karşı açılan mahkemeyi kazanmak için kanıt olarak kullanılmaktadır. Nitekim örgütler özür içeren ifadelerden yasal nedenlerden dolayı kaçınmaktadır. Ancak araştırmalar özür stratejisinin kullanımının en iyi krize yanıt stratejisi olduğunu fazlasıyla vurgulamaktadır (Benoit ve Drew, 1997; Benoit, 1995). Özür stratejisi hem en çok tercih edilen strateji olarak hem de örgütün itibarını olumlu anlamda en fazla etkileyen strateji olarak tespit edilmektedir (Ki ve Nekmat, 2014; Dean, 2004; Bradford ve Garrett, 1995). Nitekim Brinson ve Benoit'e (1999) göre paydaşlar genellikle krizdeki sorumluluğunu kabul eden ve bundan dolayı pişmanlık duyan örgütlere sempati duymaktadır. Ayrıca özür dilemek kaybolan güveninin geri kazanılması için de oldukça gereklidir (Çelebi ve Sezer, 2017a). Dolayısıyla örgütler krizden dolayı karşı karşıya kaldığı suçlamalarda hatalıysa, ilk olarak sorumluluğu kabul etmeleri ve özür dilemeleri önerilmektedir (Benoit, 1997).

Diğer taraftan acıyı paylaşma/anlayış stratejisi de örgütler tarafından kurbanların intiyaçlarına odaklandığı ve ekonomik olduğu için sıklıkla tercih edilen bir stratejidir. Coombs ve Holladay'e (2008) göre acıyı paylaşma/anlayış stratejisi örgütün krizden etkilenen paydaşlarına karşı göstermiş olduğu nezaket olarak değerlendirilebilir. Acıyı paylaşma/anlayış stratejisi temelinde kurgulanan mesajlar kurbanlar için kaygıyı içerir. Bu strateji paydaşlarla yüksek düzeyde uyum sağlama amacı taşır (Sturges, 
1994). Bazı çalışmalar daha az masraflı olan acıyı paylaşma/anlayış stratejisinin de paydaşların örgüt hakkındaki algısını şekillendirme konusunda özür stratejisi kadar etkili olduğunu göstermektedir. Çünkü her iki strateji de kurbanların ihtiyaçlarına odaklanmaktadır. Bu nedenle özür stratejisi yerine acıyı paylaşma/anlayış stratejisinin de kullanımı önerilmektedir. Ancak yönetim krizin sorumluluğunun gerçekten örgütte olduğunu biliyorsa ya da kriz gerçekten örgütsel bir hatadan kaynaklanmışsa etik olarak özür stratejisinin kullanımı önerilmektedir. Bu durumda sorumluluktan kaçmak etik dışı bir davranıştır. Sorumluluğun bilinmiyor ya da belirsiz olduğu durumlarda sorumluluğu kabul etmeden acıyı paylaşma/anlayış stratejisi önemli bir seçenek olabilir (Coombs ve Holladay, 2008).

Kriz dönemleri karmaşa ve belirsizlik içerdiği için paydaşların bilgilendirilmeleri son derece önemlidir (Mitroff, 2004). Bilgilendirici strateji doğrultusunda oluşturulan mesajlar sadece krizde ne olduğunu paydaşlara aktarır. Eğer bu bilgilendirme proaktif bir şekilde yapılırsa örgüte avantaj sağlayabilir (DiStaso vd., 2015). Aksi takdirde örgütten gelen bilgi miktarı konusunda tatmin olmayan paydaşlar farklı bilgi kaynaklarına yönelebilir (Stephens ve Malone, 2009). Schultz ve diğerleri (2011) bu stratejinin krizin olumsuz etkileri karşısında özür ve acıyı paylaşma/anlayış stratejilerine göre daha etkili olduğunu tespit ederken, Coombs ve Holladay (2008) ise bilgilendirici stratejinin kurumsal itibarı etkilemesi bakımından özür ve acıyı paylaşma/ anlayış stratejilerinin gerisinde kaldığını tespit etmiştir. Dolayısıyla krize yanıt stratejisi olarak özür, acıyı paylaşma/anlayış, ve bilgilendirme stratejilerinin etkililiği üzerinde bir fikir birliği oluşmamıştır (Schultz vd., 2011; Coombs ve Holladay, 2008). Özür ve acıyı paylaşma / anlayış stratejilerini karşılaştıran çalışmaların yetersizliği nedeniyle hangisinin daha etkili olduğu tartışma konusudur.

Nitekim krize yanıt verme stratejileri opsiyoneldir ve kriz yöneticileri krizin durumuna göre itibarını korumak ve örgütsel meşruiyeti yeniden oluşturmak için en uygun stratejiyi belirler (Coombs, 2006). Krizler örgütsel meşruiyeti tehdit ettiği için aynı zamanda örgütün itibarına da zarar verme potansiyeline sahiptir. Kurumsal itibar kriz dönemlerinde tehdit altında kalan örgütün en değerli soyut varlığı (Davies vd., 2003; Fombrun ve van Riel, 2003) olarak görülür. Paylaşılan tüm bireysel paydaş izlenimlerinin sonucu olarak kuruma uzun süreler sonunda atfedilen kolektif bir değerlendirme olarak tanımlanan kurumsal itibar kavramı, aynı zamanda güveni de oluşturan temel bir bileşen olarak düşünülmektedir (Coombs ve Holladay, 2001; Fombrun, 1996). Nitekim kurumsal itibar algısı paydaşların örgüte ilişkin güven algılarını pozitif yönlü etkilemektedir (Karakaya ve Gök Demir, 2016). Güven algısı kurumsal itibarın bir çıktısı olarak da düşünülmektedir (Ingenhoff ve Sommer, 2008). Blois'e (1999) göre güçlü bir kurumsal itibar algısı, paydaşların örgütten gelen mesajlara güvenmelerini sağlamaktadır. Dolayısıyla kriz dönemlerinde seçilecek olan krize yanıt stratejileri sadece kurumsal itibarı etkilemekle kalmaz, aynı zamanda paydaşların örgüte ilişkin güven algılarını da etkilemektedir. Çünkü örgütsel açıdan güven karşı tarafın açık, dürüst, sorumluluklarını yerine getiren ve diğerini sömürmekten kaçınacağına ilişkin paylaşılan grup algısıdır (Hon ve Grunig, 1999; Cummings ve Bromiley, 1996). Kriz dönemlerinde en uygun krize yanıt stratejisi seçilerek paydaşların var olan olumlu 
güven algısı sürdürülmelidir. Paydaşlar örgütten gelen mesajların açıklık, doğruluk ve bütünlük içerisinde kurgulandığına inanırsa örgüte ilişkin var olan davranışsal niyetlerinin de devam etmesi beklenmektedir (Eberle vd., 2014; Ingenhoff ve Sommer, 2008). Çünkü davranışsal niyetlerin ardında tutumlar yer almaktadır (Zeithaml vd., 1996). Olumlu tutuma sahip olan paydaşların örgütle olan etkileşiminin gelişeceği ve bu şekilde devam edeceği dolayısıyla paydaşları elde tutma stratejisinin pekişeceği belirtilmektedir (Morgan ve Hunt, 1994). Sonuç olarak paydaşlar örgütlerin itibarlarını güçlü bulduğunda o örgüte daha fazla güvenmekte ve bu durum olumlu davranışsal niyeti pekiştirmektedir. Dolayısıyla kriz dönemlerinde tehdit altında kalan kurumsal itibar, güven ve davranışsal niyeti olumsuz etkilemektedir. Bu nedenle kriz süresince sosyal medya üzerinden krize yanıt verme stratejilerinin stratejik olarak belirlenmesi kritik öneme sahiptir. Her krize yanıt stratejisi kurumsal itibarı korumada aynı etkiyi yaratmadığı için ampirik olarak karşılaştırmalı bir şekilde araştırılması gerekmektedir. Bu doğrultuda bu çalışmanın amacı krize yanıt stratejilerinden özür, acıyı paylaşma/ anlayış ve bilgilendirici stratejileri arasında algılanan kurumsal itibar, güven ve davranışsal niyet açısından bir farklılık yaratıp yaratmadığını incelemektir.

\section{Yöntem}

Araştırmanın amacı krize yanıt stratejilerinden özür, anlayış ve bilgilendirici stratejiler arasında algılanan kurumsal itibar, güven ve davranışsal niyet açısından bir fark olup olmadığını incelemektir. Bu amaç doğrultusunda kriz yaşayan bir örgütün sosyal medya üzerinden gerçekleştirdiği krize yanıt stratejileri için aşağıdaki araştırma soruları oluşturulmuştur:

AS1:Kriz durumu ile karşı karşıya kalan bir örgütte krize yanıt stratejilerinden özür, acıyı paylaşma/anlayış ve bilgilendirici stratejiler arasında algılanan kurumsal itibar açısından bir fark var mıdır?

AS2:Kriz durumu ile karşı karşıya kalan bir örgütte krize yanıt stratejilerinden özür, acıyı paylaşma/anlayış ve bilgilendirici stratejiler arasında kuruma duyulan güven açısından bir fark var mıdır?

AS3:Kriz durumu ile karşı karşıya kalan bir örgütte krize yanıt stratejilerinden özür, acıyı paylaşma/anlayış ve bilgilendirici stratejiler arasında kuruma ilişkin davranışsal niyet açısından bir fark var mıdır?

Veriler alan araştırması yöntemi ile Antalya ilinde Ekim 2016 yılında toplanmıştır. Uygunluk örneklemi ile Facebook kullanıcısı 1080 üniversite öğrencisi ile araştırma gerçekleştirilmiştir. Verilerin toplanmasında önceden oluşturulmuş kapalı uçlu anket formu kullanılmıştır. Deneysel tasarıma dayanan anket bir metin içermektedir: "Türkiye'de geniş otobüs filosuna sahip bir otobüs firması son 1 ayda 2 kez kaza yapmış ve toplamda 5 yolcu hayatını kaybetmiş ve 4'ü ağır olmak üzere 38 yolcu yaralanmıştır". Muhtemel önyargı ya da geçmiş deneyimleri kontrol altında tutmak için bilinçli bir şekilde firma ismi verilmemiş, simgesel bir ulaşım firması tercih edilmiştir. 
Bu firmanın kurumsal Facebook hesabından krize yanıt stratejileri doğrultusunda oluşturmuş olduğu paylaşımları incelenmektedir. Her bir katılımcı ulaşım firmasının Facebook üzerinden paylaşmış olduğu krize yanıt stratejilerinden birine maruz bırakılmıştır. Katılımcı kurumsal itibar, güven ve davranışsal niyete ilişkin soruları, maruz kalmış olduğu krize yanıt stratejisine göre cevaplamıştır. 360 katılımcı özür stratejisine, 360 katılımcı acıyı paylaşma/anlayış stratejisine ve 360 katılımcı bilgilendirici stratejiye maruz bırakılmıştır. Böylece krize yanıt stratejileri arasında algılanan kurumsal itibar, güven ve davranışsal niyet açısından bir fark olup olmadığı belirlenecektir.

Özür stratejisine maruz kalan katılımcı ulaşım firmasının Facebook üzerinden paylaştığı aşağıdaki metni okumaktadır:

"Son 1 ayda meydana gelen kazalardan dolayı yaşanan kayıpların sorumluluğunu kabul etmekteyiz. Tüm kamuoyundan ve özellikle hayatını kaybedenlerin yakınlarından ve yaralananlardan özür diliyoruz.

Acıyı paylaşma/anlayış stratejisine maruz kalan katılımcı ulaşım firmasının Facebook üzerinden paylaştığı aşağıdaki metni okumaktadır:

"Son 1 ayda meydana gelen kazalardan dolayı yaşanan kayıplardan derin üzüntü duymaktayız. Hayatını kaybedenlere Allahtan rahmet ve yakınlarına başsağlığı diliyoruz. Aynı zamanda yaralılara da acil şifalar diliyoruz."

Bilgilendirici stratejiye maruz kalan katılımcı ulaşım firmasının Facebook üzerinden paylaştığı aşağıdaki metni okumaktadır:

"Son 1 ayda firmamıza ait 2 aracımız kaza yapmıştır. 5 yolcu hayatını kaybetmiş ve 4'ü ağır olmak üzere 38 yolcu yaralanmıştır. Firmamız kazaların nedenlerini derinlemesine araştırmaktadır."

Krize yanıt stratejilerinin algılanan kurumsal itibar, güven ve davranışsal niyet açısından bir fark yaratıp yaratmadığını araştırmak amacıyla anket formu 23 sorudan oluşmaktadır. 4 soru demografik özellikleri tanımlamak için tasarlanmıştır. Kurumsal itibarı ölçmek için Ponzi ve diğerlerinin (2011) ölçeği temel alınarak 5 soru; güveni ölçmek için Hon ve Grunig'in (1999) ölçeği temel alınarak 6 soru ve davranışsal niyeti ölçmek için DiStaso ve diğerlerinin (2015) ölçeği temel alınarak 6 soru tasarlanmıştır. Demografik sorular hariç ankette yer alan tüm sorular 5 noktalı Likert tipi ölçekle ölçülmüştür.

\section{Bulgular}

\section{Demografik Bulgular}

Araştırmaya katılan 1080 katılımcının \%51'i erkeklerden oluşurken \%49'u kadınlardan oluşmaktadır. Katıımcıların aylık gelirleri 250 TL ile 35.000 TL arasında değişmekte ve 
ortalama aylık gelirleri 2.442 TL olarak hesaplanmıştır. Aylık gelir dağılımı arasındaki var olan fark katılımcıların üniversite öğrencisi olması ile ilişkilendirilmektedir. Katılımcıların internette geçirdikleri ortalama günlük süre 1 ile 17 saat arasında değişmekte ve internette geçirdikleri ortalama süre günlük 2.79 saat olarak hesaplanmıştır.

\section{Ölçme Aracının Geçerliliği ve Güvenilirliği}

Ankette yer alan ölçeklerin güvenilirliğini test etmek amacıyla Cronbach Alfa değerleri hesaplanmıştır. Kurumsal itibar için hesaplanan değer 0.898 olarak; güven için hesaplanan değer 0.847 olarak ve davranışsal niyet için hesaplanan değer 0.664 olarak tespit edilmiştir. Tüm ölçeklerin güvenilir olduğu sonucuna ulaşılmıştır.

Örneklem yeterliliğini test etmek amacıyla KMO ve Bartlett'in Küresellik testi değerleri hesaplanmıştır. Kurumsal itibar için KMO 0.865 ve Bartlett'in Küresellik testi değerleri $(p<0.01)$ olarak; güven için KMO 0.877 ve Bartlett'in Küresellik testi değerleri $(p<0.01)$ olarak ve davranışsal niyet için KMO 0.664 ve Bartlett'in Küresellik testi değerleri $(p<0.01)$ olarak hesaplanmıştır. Hair vd., (2006) KMO değerlerinin 0,50'nin üzerinde olmasının kabul edilebilir, 0,50-70 arasının orta, 0,70 üzeri değerlerin ise ayırt edici ve güvenilir bir faktör analizine işaret ettiğini ifade etmişlerdir.

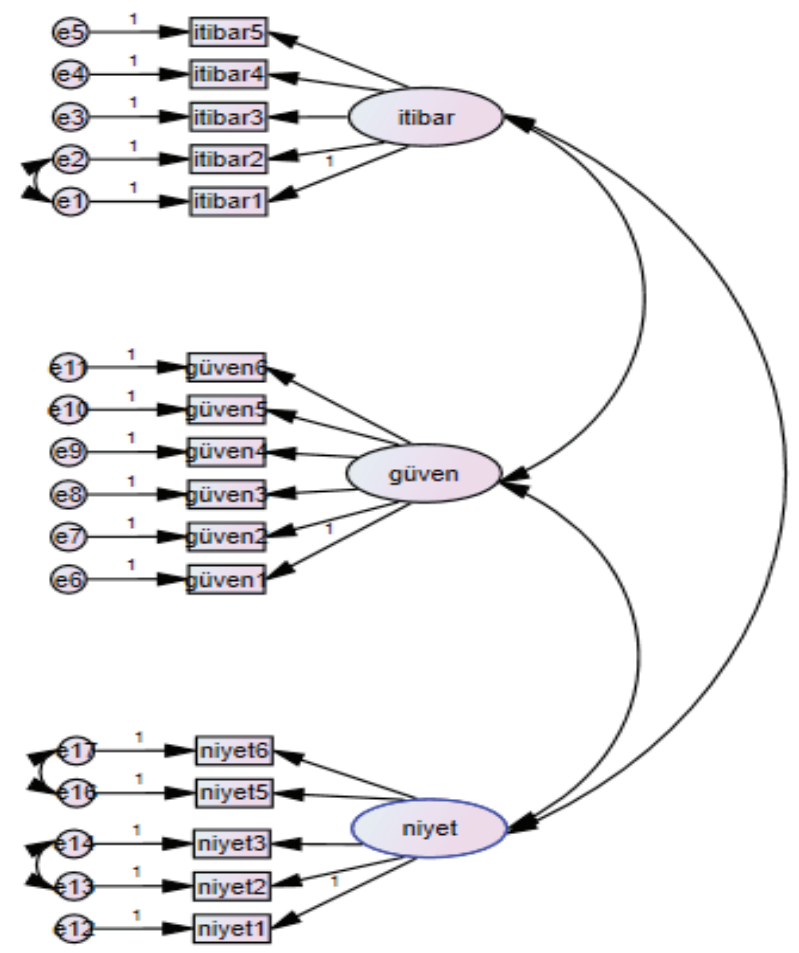

Şekil 1: Doğrulayıcı Faktör Analizi 
Araştırmanın geçerliliğini test etmek amacıyla IBM SPSS AMOS 24 ile doğrulayıcı faktör analizi uygulanmıştır (Şekil 1). Doğrulayıcı faktör analizi sonuçlarına göre doğrulayıcı faktör analizi için hesaplanması gereken uyum iyiliği değerleri (Brown, 2006; 2015) $\mathrm{CMIN} / \mathrm{df}=5,751, \mathrm{CFI}=0,940, \mathrm{TLI}=0,926$ ve $\mathrm{RMSEA}=0,66$ olarak hesaplanmıştır . $\mathrm{CMIN} / \mathrm{df}<5, \mathrm{CFI}>0,90, \mathrm{TLI}>0,90$ ve $\mathrm{RMSEA}<0,08$ değerleri yapısal eşitlik modelleri için kabul edilebilir değerlerdir. Doğrulayıcı faktör analizi sonuçlarının istatistiksel olarak kabul edilebilir sınırlar içerisinde yer almaktadır. Niyet boyundan niyet4 maddesi "Otobüs firmasının bu olay karşısındaki tavrını kınamak için kendim karşı bir Facebook grubu oluştururum" sorusu geçerliliği bozduğundan dolayı çıkartılmıştır. Modifikasyon indisleri itibar1 ile itibar2, niyet2 ile niyet3 ve niyet5 ile niyet6 sorularının hata terimleri arasında kovaryans olduğunu göstermektedir. Bu kovaryanslar aynı faktör içerisinde olduğundan dolayı yapısal eşitlik modellemesi açısından sorun teşkil etmemektedir. Sonuç olarak araştırmada kullanılan ölçeğin güvenilir ve geçerli bir ölçek olduğu kabul edilmiştir.

\section{Araștırma Sorularının Test Edilmesi}

Krize yanıt stratejilerinden özür, acıyı paylaşma/anlayış ve bilgilendirici stratejilerinin algılanan kurumsal itibar, güven ve davranışsal niyet açısından bir farklılık yaratıp yaratmadığını incelemek amacıyla tek yönlü varyans analizi gerçekleştirilmiştir.

Ancak ANOVA testi yapılmadan önce verilerin normal dağılıma uyup uymadığını test etmek amacıyla çarpıklık ve basıklık (Skewness ve Kurtosis) değerleri incelenmiştir (Tablo 1). Verilerin çarpıkıı ve basıklık değerlerinin (-)2 ile (+)2 arasında olması istatistiksel olarak verilerin normal dağıldığının ölçütüdür (Trochim ve Donnelly, 2006; Field, 2000; 2009; Gravetter ve Wallnau, 2014).

Tablo 1. Veri Seti için Çarpıklık ve Basıklık Katsayıları

\begin{tabular}{|l|c|c|c|c|}
\hline & \multicolumn{2}{|c|}{ Carpıklik } & \multicolumn{2}{c|}{ Basıklık } \\
\cline { 2 - 5 } & İstatistik & $\begin{array}{c}\text { Standart } \\
\text { Hata }\end{array}$ & İstatistik & $\begin{array}{c}\text { Standart } \\
\text { Hata }\end{array}$ \\
\hline $\begin{array}{l}\text { Bu otobüs firmasına olumlu duygular } \\
\text { beslemekteyim }\end{array}$ &, 675 &, 074 &,- 329 &, 149 \\
\hline Bu otobüs firmasına güvenirim &, 687 &, 074 &,- 251 &, 149 \\
\hline Bu otobüs firması saygın bir kurumdur &, 259 &, 074 &,- 748 &, 149 \\
\hline Bu otobüs firmasını beğenirim &, 483 &, 074 &,- 550 &, 149 \\
\hline Bu otobüs firması itibarlı bir kurumdur. &, 200 &, 074 &,- 719 &, 149 \\
\hline $\begin{array}{l}\text { Bu otobüs firması benim gibi insanlara eșit } \\
\text { davranır }\end{array}$ &,- 117 &, 074 &,- 550 &, 149 \\
\hline $\begin{array}{l}\text { Bu otobüs firması ne zaman önemli bir karar } \\
\text { alacak olsa, benim gibi insanları düșünerek } \\
\text { hareket eder. }\end{array}$ &, 218 &, 074 &,- 429 &, 149 \\
\hline
\end{tabular}




\begin{tabular}{|l|c|c|c|c|}
\hline $\begin{array}{l}\text { Bu otobüs firması sözlerini yerine getirme } \\
\text { konusunda güvenilirdir. }\end{array}$ &, 154 &, 074 &,- 493 &, 149 \\
\hline $\begin{array}{l}\text { Bu otobüs firmasının karar verirken benim gibi } \\
\text { insanların fikrini alacağını düșünürüm. }\end{array}$ &, 212 &, 074 &,- 598 &, 149 \\
\hline $\begin{array}{l}\text { Bu otobüs firmasının alanında yetkin olduğu } \\
\text { konusunda güvenim tamdır. }\end{array}$ &, 375 &, 074 &,- 576 &, 149 \\
\hline $\begin{array}{l}\text { Bu otobüs firması söz verdiği konuları yerine } \\
\text { getirir. }\end{array}$ &, 076 &, 074 &,- 353 &, 149 \\
\hline $\begin{array}{l}\text { Bu otobüs firmasının Facebook üzerinden yaptığı } \\
\text { bu açıklamayı beğenirim (like). }\end{array}$ &, 461 &, 074 &,- 953 &, 149 \\
\hline $\begin{array}{l}\text { Bu otobüs firmasının Facebook üzerinden yaptığı } \\
\text { bu açıklamayı kendi sayfamda paylașııım. }\end{array}$ &, 845 &, 074 &,- 313 &, 149 \\
\hline $\begin{array}{l}\text { Bu otobüs firmasının Facebook üzerinden yaptığı } \\
\text { bu açıklamaya yorum yazarım. }\end{array}$ &, 394 &, 074 &,- 994 &, 149 \\
\hline Yine bu otobüs firmasına giderim & 1,036 &, 074 &, 058 &, 149 \\
\hline Bu otobüs firmasını tanıdıklarıma öneririm. & 1,005 &, 074 &, 011 &, 149 \\
\hline
\end{tabular}

Verilerin normal dağılıma uyduğu test edildikten sonra krize yanıt stratejileri ile kurumsal itibar, güven ve davranışsal niyet arasındaki ilişki Tablo 2'de gösterilmiştir.

Tablo 2. Krize Yanıt Stratejileri ile Kurumsal İtibar, Güven ve Davranışsal Niyet Arasındaki Ilişkiyi İnceleyen ANOVA

\begin{tabular}{|c|c|c|c|c|c|c|}
\hline \multicolumn{7}{|c|}{ ANOVA } \\
\hline & & Kareler Toplamı & Df & $\begin{array}{l}\text { Karelerin } \\
\text { Ortalaması }\end{array}$ & $F$ & Anlamlılık \\
\hline \multirow[t]{3}{*}{ İtibar } & Gruplar arası & 19,191 & 2 & 9,595 & 12,181 & ,000 \\
\hline & Grup içi & 848,376 & 1077 & ,788 & & \\
\hline & Toplam & 867,567 & 1079 & & & \\
\hline \multirow[t]{3}{*}{ Güven } & Gruplar arası & 27,645 & 2 & 13,822 & 24,726 & ,000 \\
\hline & Grup içi & 602,055 & 1077 &, 559 & & \\
\hline & Toplam & 629,700 & 1079 & & & \\
\hline \multirow{3}{*}{$\begin{array}{l}\text { Davranıșsal } \\
\text { Niyet }\end{array}$} & Gruplar arası & 15,132 & 2 & 7,566 & 12,040 & ,000 \\
\hline & Grup içi & 676,759 & 1077 & ,628 & & \\
\hline & Toplam & 691,891 & 1079 & & & \\
\hline
\end{tabular}

Tablo 2'ye göre katılımcıların maruz kaldıkları krize yanıt stratejilerinin kurumsal itibar, güven ve davranışsal niyet üzerinde istatistiksel olarak anlamlı bir etkiye sahip olduğu görülmektedir ( $p<0,001)$. Katılımcıların maruz kaldıkları krize yanıt stratejileri, katılımcının ulaşım firmasının kurumsal itibarını ve güvenini algılayışı üzerinde ve 
ulaşım firmasına ilişkin davranışsal niyeti üzerinde istatistiksel olarak anlamlı bir farklılık yaratmaktadır.

Krize yanıt stratejilerinden hangisinin ulaşım firmasının algılanan kurumsal itibarı, güveni ve davranışsal niyeti üzerinde farklılık oluşturduğunu incelemek amacıyla posthoc testler yapılmıştır. Yapılan Post - Hoc Test tablo 3'te verilmiştir.

Tablo 3: Krize Yanıt Stratejileri ile Kurumsal İtibar, Güven ve Davranışsal Niyet Arasındaki İlişkiyi İnceleyen Post Hoc Test

\begin{tabular}{|c|c|c|c|c|c|}
\hline \multicolumn{6}{|l|}{ Scheffe } \\
\hline $\begin{array}{l}\text { Bağımlı } \\
\text { Değișken }\end{array}$ & (I) Strateji türü & (J) Strateji türü & $\begin{array}{l}\text { Ortalama } \\
\text { Fark (I-J) }\end{array}$ & $\begin{array}{c}\text { Standart } \\
\text { Hata }\end{array}$ & Anlamlılık \\
\hline \multirow[t]{6}{*}{ İtibar } & \multirow[t]{2}{*}{ Bilgilendirici } & Özür &,- 14889 &, 06615 & , 080 \\
\hline & & $\begin{array}{l}\text { Acıyı Paylașma/ } \\
\text { Anlayıș }\end{array}$ & ,17722* & ,06615 & ,028 \\
\hline & \multirow[t]{2}{*}{ Özür } & Bilgilendirici & ,14889 & ,06615 & ,080 \\
\hline & & $\begin{array}{l}\text { Acıyı Paylașma/ } \\
\text { Anlayıș }\end{array}$ &, $32611^{*}$ & ,06615 & ,000 \\
\hline & \multirow{2}{*}{$\begin{array}{l}\text { Acıyı Paylașma/ } \\
\text { Anlayıș }\end{array}$} & Bilgilendirici &,$- 17722^{*}$ &, 06615 & ,028 \\
\hline & & Özür &,$- 32611^{*}$ &, 06615 & ,000 \\
\hline \multirow[t]{6}{*}{ Güven } & \multirow[t]{2}{*}{ Bilgi } & Özür &,- 02130 & ,05573 &, 930 \\
\hline & & $\begin{array}{l}\text { Acıyı Paylașma/ } \\
\text { Anlayıș }\end{array}$ &, $32824^{*}$ & ,05573 & ,000 \\
\hline & \multirow[t]{2}{*}{ Özür } & Bilgilendirici & ,02130 & ,05573 &, 930 \\
\hline & & $\begin{array}{l}\text { Acıyı Paylașma/ } \\
\text { Anlayıș }\end{array}$ &, $34954^{*}$ & ,05573 & ,000 \\
\hline & \multirow{2}{*}{$\begin{array}{l}\text { Acıyı Paylașma/ } \\
\text { Anlayıș }\end{array}$} & Bilgilendirici &,$- 32824^{*}$ & ,05573 & ,000 \\
\hline & & Özür &,$- 34954^{*}$ & ,05573 & ,000 \\
\hline \multirow{6}{*}{$\begin{array}{l}\text { Davranıșsal } \\
\text { Niyet }\end{array}$} & \multirow[t]{2}{*}{ Bilgilendirici } & Özür & ,11778 & ,05908 & , 138 \\
\hline & & $\begin{array}{l}\text { Acıyı Paylașma/ } \\
\text { Anlayıș }\end{array}$ & ,28833* & ,05908 & ,000 \\
\hline & \multirow[t]{2}{*}{ Özür } & Bilgilendirici &,- 11778 & ,05908 & , 138 \\
\hline & & $\begin{array}{l}\text { Acıyı Paylașma/ } \\
\text { Anlayıș }\end{array}$ &, $17056^{*}$ & ,05908 & ,016 \\
\hline & \multirow{2}{*}{$\begin{array}{l}\text { Acıyı Paylașma/ } \\
\text { Anlayıș }\end{array}$} & Bilgilendirici &,$- 28833^{*}$ & ,05908 & , 000 \\
\hline & & Özür &,$- 17056^{*}$ & ,05908 & ,016 \\
\hline
\end{tabular}


Post hoc testlerin sonucuna göre acıyı paylaşma/anlayış stratejisine maruz kalan katılımcılar kurumsal itibarı özür ve bilgilendirici stratejiye maruz kalan katılımcılara göre daha düşük seviyede algılamaktadır. Acıyı paylaşma/anlayış stratejisine maruz kalan katılımcıların itibar ortalamaları bilgi stratejisine maruz kalan katılımcılarının ortalamalarından 0,17722 daha düşükken, özür stratejisine maruz kalan katılımcılardan 0,32611 birim daha düşüktür. Bu bulgu doğrultusunda acıyı paylaşma/anlayış stratejisinin kriz dönemlerinde kurumsal itibarı düzeltme amacıyla diğer iki stratejiye göre daha az tercih edilmesi gerektiği sucuna varılmıştır.

Krize yanıt stratejilerinin güven üzerindeki etkisi de benzer sonuçları vermektedir. Acıyı paylaşma/anlayış stratejisine maruz kalan katılımcıların güven algısı özür ve bilgilendirici stratejiye maruz kalan katılımcılara göre daha düşük seviyededir. Acıyı paylaşma/anlayış stratejisine maruz kalan katılımcıların güven ortalamaları bilgi stratejisine maruz kalan katılımcılarının ortalamalarından 0,32824 daha düşükken, özür stratejisine maruz kalan katılımcılardan 0,34954 birim daha düşüktür. Bu bulgu doğrultusunda acıyı paylaşma/anlayış stratejisinin kriz dönemlerinde güven algısını tesis etmek amacıyla diğer iki stratejiye göre daha az etkili olduğu sonucuna varılmıştır.

Krize yanıt stratejilerinin davranışsal niyet üzerindeki etkisi değerlendirildiğinde fark yaratan stratejinin yine acıyı paylaşma/anlayış stratejisi olduğu görülmektedir. Acıyı paylaşma/anlayış stratejisine maruz kalan katılımcıların davranışsal niyetleri özür ve bilgilendirici stratejiye maruz kalan katılımcılara göre daha düşük seviyededir. Acıyı paylaşma/anlayış stratejisine maruz kalan katılımcıların davranışsal niyet ortalamaları bilgi stratejisine maruz kalan katılımcılarının ortalamalarından 0,28833 daha düşükken, özür stratejisine maruz kalan katılımcılardan 0,17056 birim daha düşüktür. Dolayısıyla acıyı paylaşma/anlayış stratejisi kriz dönemlerinde olumlu davranışsal niyet oluşumuna diğer stratejilere göre daha az etkilidir.

\section{Sonuc}

Krize yanıt stratejilerinin algılanan kurumsal itibar, güven ve davranışsal niyet üzerindeki etkisini karşılaştırmalı olarak inceleyen bu çalışma deneysel tasarıma dayanmaktadır. Çalışma, kriz yönetim sürecini sosyal medya üzerinden kurgulayan simgesel bir ulaşım firmasının yaşadığı krize ilişkin paylaşmış olduğu mesajların etkililiği üzerine odaklanmaktadır. Bu doğrultuda krize yanıt stratejilerinden özür, acıyı paylaşma/anlayış ve bilgilendirici stratejiler arasında algılanan kurumsal itibar, güven ve davranışsal niyet açısından bir farklııı yaratıp yaratmadığı incelenmiştir. Çalışmanın sonucunda katılımcıların maruz kaldıkları krize yanıt stratejilerinin kurumsal itibar, güven ve davranışsal niyet üzerinde istatistiksel olarak anlamlı bir etkiye sahip olduğu tespit edilmiştir. Nitekim aynı araştırmacıların krize yanıt stratejilerinden biri olan Benoit'in (1995) imaj düzeltme stratejilerinin algılanan kurumsal itibar, güven ve davranışsal niyet üzerindeki etkisini inceleyen bir önceki çalışmalarında (Erendağ Sümer vd., 2017), imaj düzeltme stratejilerinin kurumsal itibar ve güven üzerinde etkisinin olduğu ancak davranışsal niyet üzerinde bir etkisinin olmadığı tespit edilmiştir. Nitekim çalışmalarında tutum ve öznel normlardan etkilenen 
kompleks bir yapı olan davranışsal niyetin kriz dönemlerinde Benoit (1995) tarafından tanımlanan imaj düzeltme stratejilerinden etkilenerek oluşmadığı tespit edilmiştir. Ancak mevcut çalışma krize yanıt stratejilerinden özür, acıyı paylaşma/anlayış ve bilgilendirici stratejinin davranışsal niyet üzerinde de etkisi olduğunu göstermektedir. $\mathrm{Bu}$ doğrultuda kriz dönemlerinde olumlu davranışsal niyet üzerinde etki sağlamak amacıyla örgütler için Benoit'in (1995) tanımladığı imaj düzeltme stratejileri yerine bu üç strateji önerilmektedir.

Krize yanıt stratejilerinin kurumsal itibar, güven ve davranışsal niyet üzerindeki etkisi karşılaştırmalı olarak incelendiğinde fark yaratan stratejinin üç değişken üzerinde de acıyı paylaşma /anlayış stratejisi olduğu tespit edilmiştir. Acıyı paylaşma /anlayış stratejisine maruz kalan katılımcıların diğer iki stratejiye maruz kalan katılımcılara göre kurumsal itibar, güven ve davranışsal niyet algılarının daha düşük olduğu ortaya konmuştur. Bu doğrultuda kurumsal itibarı düzeltme, güven algısını koruma ve olumlu davranışsal niyeti devam ettirme amacıyla acıyı paylaşma/anlayış stratejisinin kriz dönemlerinde diğer iki stratejiye göre daha az tercih edilmesi gerektiği sonucuna varılmıştır. Bu çalışma kapsamında acıyı paylaşma/anlayış stratejisinin özür ve bilgilendirici stratejiye oranla daha az etkili olduğu söylenebilir. Krize yanıt stratejisi olarak özür, acıyı paylaşma/anlayış ve bilgilendirme stratejilerinin etkililiği üzerinde literatürde henüz bir fikir birliği bulunmadığı ve bu stratejilerin etkinliğini karşılaştıran çalışmaların yetersiz olması nedeniyle bu çalışmanın bulgularının kriz iletişim alanına acıyı paylaşma/anlayış stratejisinin diğer iki stratejinin gerisinde kaldığı bulgusu ile katkı sağlayacağı düşünülmektedir. Nitekim bu bulgu acıyı paylaşma/anlayış stratejisi doğrultusunda kurgulanan mesajların bilgilendirici stratejiye göre daha az etkili olduğunu ortaya koyan DiStato ve diğerlerinin (2015) çalışması ile de uyumludur. Ayrıca araştırmanın bulguları kurumsal itibarı pozitif yönlü etkileyen özür stratejisi kullanımını olumlayan çalışmalar ile de paralellik göstermektedir. Ancak araştırma bulguları sadece bilgilendirici stratejinin kurumsal itibarı etkilemesi bakımından özür ve acıyı paylaşma/anlayış stratejilerinin gerisinde kaldığını ortaya koyan çalışma (Coombs ve Holladay, 2008) ile örtüşmemektedir. Bu doğrultuda krize yanıt stratejilerinin etkililiğini karşılaştırmalı olarak analiz eden çalışma alanlarının genişletilmesi gerekmektedir. Her krize yanıt stratejisi kurumsal itibarı korumada aynı etkiyi yaratmadığı için ampirik olarak karşılaştırmalı bir şekilde farklı kriz türleri temel alınarak farklı örneklem büyüklüğü ve çeşitliliği ile araştırılması önerilmektedir. Çünkü örgütün krize yanıt stratejileri krizden etkilenen farklı paydaş kategorilerine göre de farklılaşabilir. Ayrıca bu çalışma kapsamında her bir katılımcı sadece bir krize yanıt stratejisine maruz bırakılmış ve bu doğrultuda algıları incelenmiştir. Daha sonra yapılacak çalışmalar için her bir katılımcının krize yanıt stratejilerinden üçüne de eş zamanlı maruz bırakılarak algılarının ölçülmesi önem taşımaktadır.

\section{Kaynakça}

Akbulut, E. (2016). Durumsal Kriz İletişimi Teorisi Çerçevesinde Örgüt-Kamu İlişkisinin ve Kriz Tepki Stratejilerinin Sorumluluk Atfetme Düzeyine ve Örgütsel İtibar Algısına Etkileri. Gümüşhane Üniversitesi Illetişim Fakültesi Elektronik Dergisi, 4(1), 50-81. 
Arpan, L. M., \& Roskos-Ewoldsen, D. R. (2005). Stealing Thunder: Analysis Of The Effects Of Proactive Disclosure Of Crisis Information. Public Relations Review, 31(3), 425-433.

Aslan, P. (2015). Kriz iletişimi Yönetimi, Sosyal Medya ve Liderlik: 'Baltimore Olayları'nda

Barack Obama ve Hillary Clinton'ın Twitter Mesajlarına Dair Bir İnceleme. İstanbul Üniversitesi İletişim Fakültesi Dergisi, 49, 15-30.

Bat, M \& Yurtseven, Ç. (2014). Sosyal Medyada Kurumsal Kriz Yönetimi: Onur Air Örneği, Gümüşhane Üniversitesi Illetişim Fakültesi Elektronik Dergisi, 2(3), 197-223

Benoit, W. L. (1997). Image Repair Discourse and Crisis Communication. Public Relations Review, 23(2):177-186.

Benoit, W. L. 1995. Accounts, Excuses, And Apologies: A Theory Of Image Restoration Strategies. Albany: State University of New York Press.

Benoit, W. L., \& Drew, S. (1997). Appropriateness and Effectiveness of Image Repair Strategies. Communication Reports, 10(2), 153-163.

Blois, K. J. 1999. Trust In Business To Business Relationships: An Evaluation Of Its Status. Journal of Management Studies, 36(2):197- 215.

Bradford, J. L., \& Garrett, D. E. (1995), The Effectiveness of Corporate Communicative Responses To Accusations Of Unethical Behavior. Journal of Business Ethics, Vol. 14, 875-92.

Brinson, S. L., \& Benoit, W. L. (1999). The Tarnished Star: Restoring Texaco's Damaged Public Image. Management Communication Quarterly, 12: 483- 510.

Brown, T. A. (2006). Confirmatory Factor Analysis for Applied Research. New York, NY: The Guilford Press.

Brown, T. A. ( 2015). Confirmatory Factor Analysis for Applied Research. New York, NY: The Guilford Press

Canpolat, N., \& Şahiner, N. (2017). İmaj Restorasyon Teorisi Mesaj Stratejileri Çerçevesinde Samsung Galaxy Note 7 Güvenlik Krizinin İncelenmesi, The Turkish Online Journal of Design, Art and Communication, 7(2), 213-225.

Cohen, J. R. (1999). Advising Clients to Apologize. Southern California Law Review, 72, 10091073.

Coombs, T. W. (1995). Choosing the Right Words: The Development Of Guidelines For The Selection of the Appropriate Crisis Response Strategies. Management Communication Quarterly, $8,447-476$

Coombs, T. W. (2006). The Protective Powers Of Crisis Response Strategies: Managing Reputational Assets During A Crisis. Journal of Promotion Management, 12, 241-260.

Coombs, T. W. (2007). Protecting Organization Reputations During A Crisis: The Development And Application Of Situational Crisis Communication Theory. Corporate Reputation Review, 10(3), 163-176. 
Coombs, T. W., \& Holladay, S. J. (1996). Communication and Attributions in A Crisis: An Experimental Study in Crisis Communication. Journal of Public Relations Research, 8(4), 279295.

Coombs, T. W., \& Holladay, S. J. (2008). Comparing Apology To Equivalent Crisis Response Strategies: Clarifying Apology's Role And Value in Crisis Communication. Public Relations Review, 34(3), 252-257.

Cummings, L. L., \& Bromiley, Philip (1996). The Organizational Trust Inventory (OTI): Development and Validation. In R. Kramer, \& T. Tyler (Eds.), Trust in organizations (302-330). Thousand Oaks, CA: Sage.

Çelebi, E., \& Sezer, N. (2017a). İlişkisel Memnuniyetin Kriz Illetişim Stratejileri Üzerine Etkisi, Erciyes Illetişim Dergisi Akademia, 5 (2), 348-364.

Çelebi, E., \& Sezer, N. (2017b). Kurumsal İtibarın Kriz İletişim Stratejileri Üzerine Etkisi, Akdeniz Iletişim Dergisi, 27, 116-134.

Çelik A., \& Çakır, B. Ö. (2015). Kayıp Krizi Nasıl Fırsat Krizine Dönüştü? Türkiye, ABD ve AB Ülkelerinden Seçilmiş İşletmeler Örneği. Selçuk Üniversitesi Sosyal Bilimler Enstitüsü Dergisi, 33, 35-44.

Çetin M., \& Toprak, Y. E. (2016). Kriz Illetişimi ve Sosyal Medya: Emisyon Krizinde Volkswagen'in Facebook Kullanımı. Selçuk Iletişim, 9 (3), 54-68.

Çınarlı, İ. (2014). Bir Kriz Illetişimi Yönetimi Vaka Analizi: Kaybolan Malezya Havayolları MH370 Sefer Sayılı Uçağı. İletişim Kuram ve Araştırma Dergisi, 38, 96-115.

Davies, G., Chun, R., da Silva, R. V., \& Roper, S. (2003). Corporate reputation and competitiveness. New York: Routledge.

Dawar, N., \& Pillutla, M. M. (2000). Impact of Product-Harm Crises On Brand Equity: The Moderating Role Of Consumer Expectations. Journal of Marketing Research, 27, 215-226.

Dean, D. H. (2004). Consumer Reaction To Negative Publicity Effects Of Corporate Reputation, Response, And Responsibility For A Crisis Event. Journal of Business Communication, 41(2), 192-211.

Distaso, M. W., Vafeiadis, M. \& Amaral, C. 2015. "Review Managing A Health Crisis On Facebook: How The Responsestrategies Of Apology, Sympathy, And Information İnfluence Public Relations." Public Relations Review. 41, 222-231.

Duğan, Ö. (2018). Sosyal Medya Kaynaklı Krizlerin ‘İmaj Restorasyon Teorisi’ Açısından Örnek Olaylar Üzerinden İncelenmesi. Akdeniz İletişim Dergisi, 29, 294- 313.

Eberle, L., Milan, G., \& Matos, C. (2016). Antecedents to Customer Retention in a Corporate Context. Brazilian Business Review, 13(1), 1-23.

Erendağ Sümer, F., Gök Demir, Z., \& Karakaya Şatır Ç. (2017). The Effect of Image Repair Strategies on Corporate Reputataion, Trust and Behavioral Intentions. Ordu Üniversitesi Sosyal Bilimler Araştırmaları Dergisi, 7(3), 519-527. 
Field, A. (2000). Discovering statistics using spss for windows. London-Thousand Oaks- New Delhi: Sage publications.

Field, A. (2009). Discovering statistics using SPSS. London: SAGE.

Floreddu, P., Cabiddu, F., \& Evaristo, R. 2014. Inside Your Social Media Ring: How To Optimize Online Corporate Reputation. Business Horizons 57(6), 737-745.

Fombrun, C. J. (1996). Reputation: Realizing Value from the Corporate Image. Boston: Harvard Business School Press.

Fombrun, C. J., \& van Riel, C. B. M. (2003). Fame \& Fortune: How Successful Companies Build Winning Reputations. New York: Prentice Hall Financial Times.

Freberg, K. (2012). Intention To Comply With Crisis Messages Communicated Via Social Media. Public Relations Review 38(3), 416-421.

Fuchs-Burnett, T. (2002). Mass Public Corporate Apology. Dispute Resolution Journal, 57(3), 26-32.

Gonzalez-Herrero, A., \& Smith S. (2008). Crisis Communications Management on the Web: How Internet-Based Technologies are Changing the Way Public Relations Professionals Handle Business Crises. Journal of Contingencies and Crisis Management, 16(3):143-153.

Gravetter, F., \& Wallnau, L. (2014). Essentials of statistics for the behavioral sciences (8th ed.). Belmont, CA: Wadsworth.

Hair Jr. J.F., Black, W.C., Babin, B.J., Anderson, R. \& Tathum, R. (2006). Multivariate data analysis (6th ed.), Prentice Hall, Upper Saddle River.

Hon, L. \& Grunig, J. E. (1999). Measuring Relationship In Public Relations. Paper presented to the Institute for Public Relations, Gainesville, FL.

Ingenhoff, D., \& Sommer, K. (2008). The Interrelationships Between Corporate Reputation, Trust And Behavioral Intentions: A Multistakeholder Approach. 58th Annual conference of the International Communication Association (ICA). Montreal, Canada.

Kalaycı, B. N. (2017). Sosyal Medyada Kriz İletişimi: Turkcell Örneği, 1. Uluslararası İletişimde Yeni Yönelimeler Konferansı.

Karakaya, Ç., \& Gök-Demir, Z. (2016). The Role Of Corporate Reputation On Trust And Customer Behavioural Intentions: A Study On A Private Health Institution In Turkey. in: Trust In Communication Management, Okay A., ed. Peter Lang, Frankfurt, 131-156.

Kellerman, B. (2006). When Should A Leader Apologize And When Not? Harvard Business Review, 84(4), 72-81.

Ki, E. J., \& Nekmat, E. (2014). Situational Crisis Communication And Interactivity: Usage And Effectiveness Of Facebook For Crisis Management By Fortune 500 Companies. Computers in Human Behavior 35, 140-147.

Mersham, G. M., Theunissen, P. \& Peart, J. G. M. (2009). Public Relations And Communication Management: An Aotearoa/New Zealand Perspective. North Shore, NZ: Pearson. 
Mitroff, I. I. (2004). Crisis leadership: Planning for the Unthinkable. Hoboken, NJ: John Wiley \& Sons Inc.

Morgan, R. M. \& Hunt, S. D. (1994). The Commitment-Trust Theory Of Relationship Marketing. The Journal Of Marketing, 58(3), 20-38.

Ngai, E., Tao, S. \& Moon, K. (2015). Social Media Research: Theories, Constructs, And Conceptual Frameworks. International Journal of Information Management 35(1), 33-44.

Özdemir, B. P., \& Yamanoğlu, M. (2010). Durumsal Kriz Iletişimi Teorisinin Türk Eczacıları Birliği (TEB) Örnek Olayı Çerçevesinde İncelenmesi. Selçuk Iletişim, 6(1), 123-136.

Patel, A., \& Reinsch, L. (2003). Companies Can Apologize: Corporate Apologies And Legal Liability. Business Communication Quarterly, 66, 17-26.

Ponzi, L. J., Fombrun, C. J. \& Gardberg, N. A. (2011). RepTrak ${ }^{\text {TM }}$ Pulse: Conceptualizing and Validating A Short-Form Measure Of Corporate Reputation. Corporate Reputation Review 14(1), 15-35.

Roshan, M., Warren, M. \& Carr, R. (2016). Understanding The Use Of Social Media By Organisations For Crisis Communication. Computers in Human Behavior 63, 350-361.

Scherp, A., Schwagereit, F., Ireson, N., Lanfranchi, V., Papadopoulos, S., Kritikos, A. Kompatsiaris, Y., \& Smrz, P. (2009). Leveraging Web 2.0 Communities in Professional Organisations. In W3C Workshop on the Future of Social Networking Barcelona, Spain.

Schultz, F., Utz, S., \& Göritz, A. (2011). Is the Medium the Message? Perceptions of and Reactions to Crisis Communication via Twitter, Blogs and Traditional Media. Public Relations Review, 37(1), 20-27.

Stephens, K. K., \& Malone, P. C. (2009). If the Organizations Won't Give Us Information...: The Use Of Multiple New Media For Crisis Technical Translation And Dialogue. Journal of Public Relations Research, 21(2), 229-239.

Sturges, D. L. (1994). Communicating Through Crisis: A Strategy For Organizational Survival. Management Communication Quarterly, 7(3), 297-316.

Şatır Ç. \& Gök Demir Z. (2010). Reaktif Halkla İlişkiler Stratejisi Olarak Örgütsel Söylemler Üzerinden Krizde İmaj Düzeltme Stratejileri: Burger King Örneği. Akdeniz Üniversitesi Illetişim Fakültesi Dergisi, Sayı 14, 1-22.

Taylor, M. \& Perry, D. C. (2005). Diffusion of Traditional And New Media Tactics in Crisis Communication. Public Relations Review 31(2), 209-217.

Trochim, W. M., \& Donnelly, J. P. (2006). The research methods knowledge base (3rd ed.). Cincinnati, OH:Atomic Dog.

Tyler, L. (1997). Liability Means Never Being Able To Say You're Sorry: Corporate Guilt, Legal Constraints, And Defensiveness in Corporate Communication, Management Communication Quarterly, 11, 51-73.

Weick, K. (1995). Sense Making in Organizations. Thousand Oaks, CA: Sage Publications. 
Yıldırım, A. (2017). Dijital Spor İletişimi Bağlamında Türk Milli Takımı'nda Yaşanan Krizin Sosyal Medyaya Yansıması. e-Journal of New Media, 1(1), 110-118.

Zeithaml, V. A., Berry, L. L., \& Parasuraman, A. (1996). The Behavioural Consequences Of Service Quality. The Journal of Marketing, 60, 31-46. 